http://nv.nltu.edu.ua

https://doi.org/10.15421/40280416

Article received 23.04.2018 p.

Article accepted $26.04 .2018 \mathrm{p}$.

L. M. Luchyshyn

удк $336.225+338.43$

luchik_Im@ukr.net

Л. М. Лучишин

Національний університет "Львівська політехніка", м. Львів, Україна

\title{
ПОДАТОК НА ПРИБУТОК: ЕВОЛЮЦІЯ, ПЕРСПЕКТИВИ ТА ПРАКТИКА ЗАСТОСУВАННЯ
}

\begin{abstract}
Закономірно, що важливим шляхом підвищення ефективності функціонування українських підприємств є удосконалення механізму оподаткування прибутку. Саме прибуток є основним критерієм ефективності підприємницької діяльності. Вплив цього податку на діяльність підприємств та економіку загалом $є$ однією з важливих проблем в умовах функціонування економічного середовища. Податок на прибуток - це той податок, який використовують в економічній політиці, що може стати ефективним інструментом для підтримки стабілізаційної та макроекономічної політики держави. Суть цього податку головним чином залежить від рівня економічного розвитку країни. Оскільки Україна обрала євроінтеграційний курс, то стає зрозумілим, що її податкова система повинна відповідати європейським прагненням. В іншому разі не буде можливим забезпечити належний рівень конкурентоспроможності вітчизняних підприємств і залучити в країну потенційних інвесторів. Недосконалість законодавства зумовлює розвиток застосування тіньових схем і суперечностей у податковому законодавстві. А це свідчить, про те, що сучасний механізм оподаткування прибутку має низку істотних недоліків. Визначено основні проблеми адміністрування податку на прибуток та його фіскальної ефективності на сьогодні, проаналізовано фактори, що впливають на динаміку надходжень та новацій щодо вдосконалення механізму оподаткування прибутку, а також акцентовано на запропоновану урядом України заміну традиційного податку на прибуток підприємств податком на виведений капітал.
\end{abstract}

Ключові слова: оподаткування прибутку; податкове навантаження; податкові різниці; податковий механізм; податок на капітал; фіскальна значущість.

Вступ. Під час оподаткування прибутку підприємств час від часу виникають питання, що стосуються порядку формування об'єкта оподаткування, умов надання податкових пільг підприємствам для стимулювання інвестиційної активності чи розвитку інноваційних процесів. Своєчасне вирішення зазначених вище питань набуває особливої актуальності, оскільки є основою вдосконалення та модернізації сучасної системи оподаткування суб'єктів господарювання в Україні. Податок на прибуток відіграє ключову роль при оподаткуванні суб'єктів господарювання, оскільки прибуток традиційно розглядають як ключову характеристику діяльності таких суб'єктів, фактичним джерелом сплати податків. Винятковість податку на прибуток полягає й у тому, що механізм його сплати дає змогу найбільш органічно забезпечувати практичне поєднання фіскальної та регуляційної функцій податків. Існування прямо пропорційної залежності між розміром прибутку і сумами податку знижує мотивацію виробників щодо об'єктивності визначення бази оподаткування, зумовлює процеси ухилень від сплати, використання податкових тіньових схем при визначенні податкового зобов'язання. Власне недосконалість законодавства зумовлює розвиток застосування таких схем і суперечностей у податковому законодавстві. Податкове навантаження української економіки стримує стимули до праці, інвестування коштів у розвиток країни, підтри- мання максимальної ефективності виробництва і розподілу, а також до участі у бізнес-проектах. Удосконалення адміністрування податку на прибуток України в умовах євроінтеграції може зробити істотний позитивний вплив на економіку країни.

Аналіз останніх досліджень та публікацій. Проблеми української податкової системи гостро відчувають як підприємці, так і науковці. Тому існує низка підходів до іiі реформування. Питання формування досконалого та раціонального механізму сплати податку на прибуток підприємств $є$ предметом наукових пошуків провідних вчених, серед яких варто відзначити праці таких авторів, як Ю. Лупенко (2016), Т. Паєнтко (2005), А. Поддєрьогін (2015), 3. Варналій (2014), К. Копчинська (2015), А. Скрипник (2016), В. А. Савчук (2013), Т. Шустваль ( 2015), М. П. Городиський (2015) та ін. Незважаючи на істотні напрацювання в цій сфері, реформування механізму сплати податку на прибуток підприємств в Україні, зокрема, в частині відмови від ведення окремого виду обліку при визначенні об'єкта оподаткування, спрощення порядку адміністрування цього податку, посилення його впливу на регулювання інвестиційної активності суб'єктів господарювання, вимагає від наукової спільноти поглиблення досліджень економічної природи цієї форми оподаткування та генерування науково обгрунтованих рекомендацій щодо подальшого його розвитку.

\section{Інформація про авторів:}

Лучишин Людмила Миколаївна, ст. викладач, кафедра обліку та налізу. Email: luchik_Im@ukr.net

Цитування за Дсту: Лучишин Л. М. Податок на прибуток: еволюція, перспективи та практика застосування. Науковий вісник НЛтУ України. Серія Економічна. 2018, т. 28, № 4. С. 88-91

Citation APA: Luchyshyn, L. M. (2018). Income Tax: Evolution, Prospects and Practice of Application. Scientific Bulletin of UNFU, 28(4), 88-91. https://doi.org/10.15421/40280416 
Мета дослідження - оцінити фіскальну ефективність податку на прибуток, проаналізувати фактори, що впливають на динаміку надходжень та новації щодо удосконалення механізму оподаткування прибутку.

Викладення основного матеріалу. Упродовж останніх років податок на прибуток підприємств перебуває у центрі уваги українського уряду та бізнесу. За своєю природою він $\epsilon$ потужним фіскальним інструментом для стимулювання інвестицій та економічного розвитку країни. В умовах економічної кризи було проведено низку реформ щодо його коригування. Так, 3 2015 р., в Україні діє порядок адміністрування податку на прибуток підприємств, який за своєю будовою є досить стандартною системою в міжнародній практиці. Така класична європейська модель оподаткування прибутку підприємств $\epsilon$ найпоширенішою серед країн СС (окрім Естонії). Втім, це не означає, що вона є безпроблемною та прийнятною для України з огляду на інституційний, політичний та економічний рівні розвитку України. Її супроводжують недоліки, серед яких такі основні:

1. Постійна та значна девальвація національної валюти призводить до нагромадження від'ємного значення об'єкта оподаткування (збитки минулих періодів), які більшою мірою пов'язані з курсовими різницями, що відкриває можливість для зловживань з базою оподаткування. Ці збитки переносяться на майбутні періоди і нівелюють поточні податкові зобов'язання. За даними Міністерства фінансів за звітний 2017 р. 8000 компаній 3 обігом понад 20 млн грн відзвітували про збитки. Нагромаджені збитки, які переносяться на майбутні періоди, можуть знизити доходи з податку на прибуток протягом кількох наступних років, оскільки збитки можна переносити протягом необмеженого періоду.

2. Наявність певною мірою ризиків, які виникають під час здійснення господарських операцій, зокрема: коригування на суми нарахованих резервів, списання безнадійної заборгованості, здійснення оцінки об'єктів обліку (активів, зобов'язань, капіталу, доходів або витрат), після здійснення яких очікується, що ризик виникне або збільшиться. Такі ризики виникають у суб'єктів господарювання, які зобов'язані здійснювати коригування фінансового результату на податкові різниці. Відповідно до п. 134 розділу ІІІ ПКУ (Pro zminy, 2014) "об'єктом оподаткування є: прибуток із джерелом походження з України та за ії межами, який визначається шляхом коригування (збільшення або зменшення) фінансового результату до оподаткування, визначеного у фінансовій звітності підприємства, на податкові різниці. У частині встановлення податкових різниць для компаній $з$ обігом понад 20 млн грн на рік фінансовий прибуток коригують для цілей оподаткування на ряд різниць (Kodeks, 2010). Надалі, розглядаючи які саме корегування фінансового результату до оподаткування встановлені ПКУ, можна визначитися із ризиками викривлення фінансового результату, зокрема:

- коригування (збільшення) "на суму нарахованої амортизації основних засобів або нематеріальних активів" відповідно до НПСБО та одночасно корегування (зменшення) "на суму розрахованої амортизації (п 138.3 ПКУ) без урахування їх переоцінки (уцінки, дооцінки), проведеної відповідно до положень бухгалтерського обліку, вказує на те, що при нарахуванні такої амортизації використовують припущення, які можуть впливати на завищення сум відповідних витрат у поточному році, а отже - призведуть до зменшення прибутку до оподаткування. До таких припущень потрібно віднести термін корисного використання активу, який несе в собі ризик невиправданого скорочення строку амортизації, i як наслідок, завищення витрат звітного періоду;

- коригування (збільшення) фінансового результату до оподаткування на суму витрат на формування резервів та забезпечень для відшкодування наступних (майбутніх) витрат відповідно до НПСБО та одночасно коригування (зменшення) фінансового результату до оподаткування на суму поточних витрат, які відшкодовані за рахунок цих резервів та забезпечень, дає змогу запобігти ризику заниження фінансового результату до оподаткування внаслідок суб'єктивної оцінки таких умовних зобов'язань, як резерв гарантійних виплат, резерв на реструктуризацію, резерв на вибуття необоротних активів тощо;

- коригування суми перевищення нарахованих у бухгалтерському обліку відсотків за кредитами, позиками та іншими борговими зобов'язаннями над $50 \%$ суми фінансового результату до оподаткування, фінансових витрат та суми амортизаційних відрахувань за даними фінансової звітності звітного податкового періоду, у якому здійснюється нарахування таких відсотків, за умов, що сума боргових зобов'язань, які виникли за операціями з пов'язаними особаминерезидентами, перевищує суму власного капіталу більше ніж у 3,5 раза. Таке коригування відіграє роль запобіжника ризику перевитрат платників податку щодо встановлених відсотків за кредитами, позиками та іншими борговими зобов'язаннями в операціях із пов'язаними особами;

- коригування за правилами трансфертного ціноутворення, які не можуть бути чітко визначені ні щоквартально протягом звітного року, ні за результатами декларування, адже Звіт про контрольовані операції згідно з 3/п.39.4.2 Податкового кодексу України подається до 1 травня року, що настає за звітним періодом, тоді як річна декларація має бути вже подана у лютому/березні. При розрахунку контрольованих операцій та застосуванні трансфертного ціноутворення з'являються суперечки стосовно діапазону цін за принципом "витягнутої руки".

До наведеного переліку можна додати ще певну кількість корегувань, що запобігають заниженню податкових зобов'язань платників податку на прибуток, але і 3 того, що наведено достатньо аргументовано, можна зробити висновок, що ризики криються насамперед у припущеннях, на які спирається визнання, оцінка і подання об'єктів в обліку і фінансовій звітності.

3. Платники податків 3 доходом меншим, ніж 20 млн грн, мають змогу не застосовувати податкові коригування, такі як резерви, мінімальні терміни амортизації, уцінку, "тонку" капіталізацію тощо. 3 огляду на це вони можуть використовувати широкий спектр законних інструментів обліку для зменшення фінансового результату та зниження податкового навантаження 3 податку на прибуток. Небажання сплачувати податки $є$ цілком природним, оскільки будь-який суб'єкт господарювання прагне захистити своє майно, зокрема, й від держави. I це прагнення практично не залежить від ступеня законослухняності (Karminska-Belobrova, 2010 , р. 271). Отже, правила оподаткування прибутку підприємств в Україні дедалі ускладнюються, однак зберігаються основні причини тінізації бізнесу та виведення капіталу та відсутність гарантій захисту права власності.

4. Фіскальна ефективність податку на прибуток підприємств. У сучасній економічній літературі фіскальна ефективність податків переважно асоціюється з їхньою питомою вагою у ВВП, доходах бюджету, податкових надходженнях. У вузькому розумінні ефективність вимірюють як частку надходжень податку у ВВП. Важливим у цьому контексті $є$ визначення питомої ваги податку на прибуток у доходах Зведеного бюджету Украіни загалом та в податкових надходженнях зокрема. Як свідчать дані Міністерства фінансів, за загальної тенденції до зростання сум податкових надходжень у ВВП, частка надходжень 3 податку на прибуток під- 
приємств значно скоротилися (від 5,3\% до $2 \%$ ВВП упродовж 2007-2017 рр.). За результатами 2017 р. надходження 3 податку на прибуток до Державного бюджету становило 44,3 млрд грн, 3 яких 24 млрд грн становлять переплати. У загальній структурі податкових надходжень податок на прибуток знизився від 15 до $8,5 \%$.

Зважаючи на наведені дані, можна зробити висновок, що зі збільшенням суми податкових надходжень від усіх податків платежів, надходження від податку на прибуток зменшуються. Враховуючи статистику надходжень 3 податку на прибуток підприємств за останні роки та значні суми переплати до бюджету цього податку, можна зазначити, що цей податок не $є$ бюджетотвірним. Динаміка надходжень 3 податку на прибуток підприємств за останні роки свідчить про поступове зменшення значення цього податку у формуванні доходної частини бюджету країни. Ситуація з очікуваними надходженнями від цього податку в умовах економічного падіння та збитковості підприємств дедалі погіршується. Наведені вище системні недоліки перетворили податок на прибуток підприємств в Україні на дієвий механізм фіскального тиску на сумлінних платників податку. Як наслідок, сутність податку наразі викривлена, він вже не $\epsilon$ "справедливим", а фіскальна ефективність податку на прибуток підприємств досить низька. Ця система неефективна і створює умови для використання великими компаніями складних схем для того, щоб уникнути оподаткування. Про це також зазначають зарубіжні та українські експерти.

Недавно уряд повернувся до ідеї запровадження в Україні податку на виведений капітал замість податку на прибуток. Податок на виведений капітал важко назвати популярним. 3-поміж розвинених юрисдикцій його застосовують тільки в Естонії. Проте такий механізм позитивно сприймають інвестори, які там працюють. Однак Україна за своїм економічним станом, територією, населенням та політичними ризиками відрізняється від Естонії. Які ж цілі переслідує законодавець у цьому випадку? Ймовірно, основну мету впровадження податку на виведений капітал закладено в назві закону, яким передбачено введення цього податку. Як випливає 3 назви, закон спрямований на поліпшення інвестиційного клімату в Україні. Сплата податку здійснюється тільки в момент розподілу прибутку. Принцип його дії насамперед спрощує ведення податкового обліку, немає потреби підтверджувати правомірність понесених витрат і сформованих збитків. Завдяки цьому спрощується ведення обліку для цілей оподаткування, істотно звужується сфера податкового контролю i, відповідно, поле для потенційного конфлікту між фіскальними органами і платниками податків. Більше того платник податків отримує можливість вирішувати, коли він готовий сплатити податок - без необхідності робити це 3 певною періодичністю. Це дає йому свободу для маневру і стимулює реінвестиції в українську економіку. Водночас, це повинно стимулювати надходження до держбюджету від інших податків - податку на додану вартість та податку з доходів фізичних осіб. Також нова система може стати наступним кроком до припинення каналів сумнівної податкової мінімізації у сфері податку на прибуток, слідом за введенням системи електронного адміністрування ПДВ, яка покінчила з "відмиванням" ПДВ. Очікується, що ці фактори повинні сприят- ливо позначитися на інвестиційній привабливості України в міжнародному рейтингу. Податок на виведений капітал повинен вирішити немало проблем (Kodeks, 2010).

На сьогодні оподаткуванню податком на прибуток підлягають і поточна діяльність бізнесу, і розподілений прибуток у формі дивідендів, відсотків та роялті. Тобто, якщо, наприклад, бізнес отримав 1000 грн і витратив 600 грн то податком у розмірі $18 \%$ буде обкладатися фінансовий результат (прибуток) у розмірі 400 грн 3 якого підприємство заплатить 72 грн податку. Якщо 3 цих 400 грн. прибутку власник-резидент виплатить дивіденди, то із суми дивідендів буде вирахувано $18 \%$ авансового внеску - за певних умов. Якщо кошти будуть переказані нерезиденту, то буде нараховано $15 \%$ податку на репатріацію. У разі застосування податку на виведений капітал прибуток у розмірі 400 грн не буде оподатковуватися, а тільки на ту суму, яка буде переказана у вигляді дивідендів або прирівняних до них платежів. Розмір ставки, як це передбачено у проекті, буде залежати від виду платежу і того, хто отримує кошти. Якщо це виплата дивідендів резиденту - платнику податку на виведений капітал, то ставка буде $0 \%$, якщо неплатнику - нерезиденту або резиденту - $15 \%$, якщо це фінансова допомога, що не повернена протягом 12 місяців - 20\%. А якщо 3 прибутку 400 грн підприємство 200 грн перерахує власнику-резиденту як дивіденди, то розмір податку становитиме 0 грн, і решта 200 грн які залишаться в компанії, оподатковуватися не будуть. На думку розробників проекту, така реформа сприятиме розвитку підприємств та економіки загалом, оскільки підприємці будуть зацікавлені в інвестуванні прибутків у розвиток власних підприємств, а податок сплачуватиметься у розмірі 15 чи 20 \% (залежно від видів операцій з виведення капіталу) тільки на ту частку прибутку, яку не капіталізовано.

Податок на виведений капітал дасть змогу створити сприятливіші умови для залучення інвестицій в Україну, а також позитивно вплине на ділову та інвестиційну активність, а також зазнає спрощення фінансова звітність підприємств. Бухгалтерії не треба буде оптимізувати фінансовий результат. Звітність стане прозорішою, зрозумілішою та привабливішою для інвесторів, зменшиться кількість підстав для проведення податкових перевірок. Як наслідок - зменшиться кількість судових справ, які блокують великі суми спірних податків. Бухгалтерський облік підприємств буде виконувати притаманну йому статистичну функцію, а саму звітність треба буде готувати у меншому обсязі, тільки стосовно визначеного кола операцій з виплати дивідендів та прирівняних до них платежів.

Висновки. Запровадження податку на виведений капітал не буде легким і безболісним. Передусім, втрат зазнає державний бюджет як мінімум на перших етапах впровадження системи. У довготерміновій перспективі iii ефективність спрогнозувати важко, особливо з урахуванням тяжіння українського бізнесу до пошуку законодавчих лазівок для непрозорої податкової оптимізації. Також існує імовірність, що зі скасуванням податку на прибуток у класичному розумінні Україна може здобути славу своєрідного офшору, що негативно позначиться на їі міжнародному іміджі, особливо з урахуванням того, що Україна, на відміну від Естонії, не входить до ЄС. 
Введення податку на виведений капітал потребує вирішення низки важливих питань, зокрема: про частку збитків, нагромаджених платниками податків до введення податку, про доцільність збереження авансового внеску при виплаті дивідендів, про періодичність подання звітності, про частку третьої групи єдиного податку, про порядок застосування системи до неприбуткових організацій.

Очевидно, що для ефективної роботи податку на виведений капітал буде потрібно комплексне реформування всієї системи оподаткування України, а також вдосконалення і лібералізація валютного регулювання.

\section{Перелік використаних джерел}

Horodyskyi, M. P., \& Panchenko, I. A. (2015). Kontseptualni zasady vnutrishnoho kontroliu prybutku, oriientovanoho na upravlinnia ryzykamy. Problemy teorii ta metodolohii obliku, kontroliu i anali$z u, \quad 2(32)$. Retrieved from: http://nbuv.gov.ua/jpdf/ecnof_2015_2(32) 12.pdf. [In Ukrainian].

Karminska-Belobrova, M. V. (2010). Napriamy reformuvannia mekhanizmu administruvannia podatkiv. Teoriia ta praktyka derzhavnoho upravlinnia, 3, 268-275. [In Ukrainian].

Kodeks. (2010). Podatkovyi kodeks Ukrainy. Zakon Ukrainy vid 02.12.2010 r., № 2755-VI. Retrieved from: http://zakon3.rada.gov.ua/laws/show/2755-17. [In Ukrainian].

Kopchynska, K. (2015). Yevropeiski tendentsii v opodatkuvanni prybutku pidpryiemstv. Naukovyi visnyk Polissia, 2, 148-153. [In Ukrainian].
Lupenko, Yu. O., \& Tulush, L. D. (2016). Opodatkuvannia silskoho hospodarstva $\mathrm{v}$ umovakh transformatsii spetsialnykh podatkovykh rezhymiv. Ekonomika APK, 1, 5-17. [In Ukrainian].

Paientko, T. V. (2005). Pidvyshchennia efektyvnosti administruvannia PnP. Naukovyi visnyk Natsionalnoi akademii DFS Ukrainy, 4, 8089. [In Ukrainian].

Poddierohin, A. M., \& Babich, V. V. (2015). Udoskonalennia opodatkuvannia prybutku na osnovi vyznachennia obiekta opodatkuvannia. Finansy Ukrainy, 9, 71-76. [In Ukrainian].

Pro zminy. (2014). Pro vnesennia zmin do Podatkovoho kodeksu Ukrainy ta deiakykh zakonodavchykh aktiv Ukrainy shchodo podatkovoi reformy. Zakon Ukrainy vid 28.12.2014 r., № 71-VIII. Retrieved from: http://zakon5.rada.gov.ua/laws/show/7119/print1453386900937086. [In Ukrainian].

Savchuk, V. A. (2013). Teoretychni zasady orhanizatsii administruvannia podatkiv. Efektyvna ekonomika. Retrieved from: $\mathrm{http}: / /$ www.economy.nayka.com.ua. [In Ukrainian].

Shustval, T. (2015). Podatok na prybutok pidpryiemstv: yak pratsiuvaty po-novomu. Vse pro bukhhalterskyi oblik, 4, 52-58. Retrieved from: http://www.vobu.com.ua/ukr/guide/view/1586. [In Ukrainian].

Skrypnyk, A. V., \& Serebrianskyi, D. M. (2016). Otsinka fiskalnoi efektyvnosti pilhovoho opodatkuvannia prybutku pidpryiemstv. Ekonomika Ukrainy, 7, 13-27. [In Ukrainian].

Varnalii, Z., \& Serebrianskyi, D. (2014). Vplyv opodatkuvannia prybutku na ekonomichnyi rozvytok Ukrainy. Ekonomika Ukrainy, 5, 55-69. [In Ukrainian].

\section{Национальный университет "Львовская политехника", г. Львов, Украина}

\section{НАЛОГ НА ПРИБЫЛЬ: ЭВОЛЮЦИЯ, ПЕРСПЕКТИВЫ И ПРАКТИКА ПРИМЕНЕНИЯ}

В условиях экономического кризиса, налоговое регулирование стало одним из основных направлений государственного влияния, направленного в поддержку финансового сектора. Важным путем повышения эффективности функционирования украинских предприятий является усовершенствование механизма налогообложения прибыли. Налог на прибыль - это тот налог, который используется в экономической политике, и может стать эффективным инструментом для поддержки стабилизационной и макроэкономической политики государства. Суть этого налога главным образом зависит от уровня экономического развития страны. Поскольку Украина избрала евроинтеграционный курс, то становится понятным, что ее налоговая система должна отвечать европейским стремлениям. В ином случае не будет возможным обеспечить надлежащий уровень конкурентоспособности отечественных предприятий и привлечь в страну потенциальных инвесторов. Несовершенство законодательства предопределяет развитие применения теневых схем и противоречий в налоговом законодательстве. А это свидетельствует о том, что современный механизм налогообложения прибыли имеет ряд существенных недостатков. Определены основные проблемы администрирования налога на прибыль и его фискальной эффективности на сегодняшний день, проведен анализ факторов, которые влияют на динамику поступлений и новаций относительно усовершенствования механизма налогообложения прибыли, а также сделан акцент на предложенную правительством Украины замену традиционного налога на прибыль предприятий, налогом на выведенный капитал.

Ключевые слова: налогообложение прибыли; налоговая нагрузка; налоговые разницы; налоговый механизм; налог на капитал; фискальная значимость.

L. M. Luchyshyn

Lviv Polytechnic National University, Lviv, Ukraine

\section{INCOME TAX: EVOLUTION, PROSPECTS AND PRACTICE OF APPLICATION}

An important way to improve the efficiency of Ukrainian enterprises operation is certainly to improve the mechanism of profit taxation. It is profit that is the main criterion for the effectiveness of entrepreneurial activity. The impact of this tax on business activities and the economy as a whole is one of the important problems in the functioning of the economic environment. Income tax is a tax that is used in economic policy, which can become an effective tool for maintaining the state's stabilization and macroeconomic policies. The essence of this tax mainly depends on the level of economic development of the country. Since Ukraine has chosen a European integration course, it becomes clear that its tax system must meet European aspirations. Otherwise, it will not be possible to ensure the proper level of competitiveness of domestic enterprises and attract potential investors into the country. The imperfection of legislation leads to the development of the use of shadow schemes and contradictions in tax legislation. This shows that the modern mechanism of profit taxation has a number of significant disadvantages. The main problems of administering the tax on profit and its fiscal efficiency for today are determined. Factors influencing the dynamics of revenues and innovations in improving the mechanism of profit taxation are analyzed. Finally, the emphasis is put on the replacement of the traditional corporate income tax by the tax on the withdrawn capital offered by the government of Ukraine. A capital tax creates preconditions for the exit of business from shade and strengthening of investment attractiveness. A capital tax was worked out by business for business that is very important.

Keywords: profit taxation; tax loading; tax differences; tax mechanism; capital tax; fiscal meaningfulness. 